\title{
Characterization of Phytophthora capsici Associated with Roots of Weeds on Florida Vegetable Farms
}

\author{
Ronald D. French-Monar, University of Florida-IFAS, Plant Pathology Department, Southwest Florida Research \& \\ Education Center, 2686 State Road 29 North, Immokalee 34142-9515; Jeffrey B. Jones, University of Florida-IFAS, \\ Plant Pathology Department, Gainesville 32611-0680; and Pamela D. Roberts, University of Florida-IFAS, Plant \\ Pathology Department, Southwest Florida Research \& Education Center, 2686 State Road 29 North, Immokalee \\ 34142-9515
}

\begin{abstract}
French-Monar, R. D., Jones, J. B., and Roberts, P. D. 2006. Characterization of Phytophthora capsici associated with roots of weeds on Florida vegetable farms. Plant Dis. 90:345-350.

Weeds were sampled in commercial vegetable fields in Palm Beach County, FL in August 2001, December 2001, and March 2002 for the presence of Phytophthora capsici. Fields sampled had a recent history of this plant pathogen. $P$. capsici was successfully isolated from the roots of six of 42 Carolina geranium (Geranium carolinianum) plants, four of 28 American black nightshade (Solanum americanum) plants, and two of 130 common purslane (Portulaca oleracea) plants. All but one of the 12 isolates were of the A1 mating type. All 12 isolates were resistant to mefenoxam, although at different levels. All but one isolate were strongly pathogenic on pepper seedlings. When two or three isolates recovered from each weed were inoculated onto the roots of their weed host of origin, $P$. capsici was recovered from the roots. Isolates of $P$. capsici were tested on four other solanaceous weeds of importance or potential importance to agricultural fields in Florida: Solanum nigrum, S. ptycanthum, S. carolinense, and S. capsicoides. Recovery of $P$. capsici from roots varied with weed species and isolate tested. $P$. capsici caused disease mortality on $S$. nigrum, and no reisolation of $P$. capsici was possible with $S$. capsicoides. This is the first report of $S$. americanum and G. carolinianum being alternative hosts for $P$. capsici under field conditions. This study also validated $P$. oleracea as an alternative host. In Florida, and perhaps elsewhere, weeds may contribute to pathogen survival in the absence of a host crop or when propagules may not readily survive in soil or plant debris.
\end{abstract}

Additional keywords: Capsicum annuum, inoculum survival, oomycete, Phytophthora blight, root rot, sources of inoculum

Phytophthora blight, caused by the oomycete Phytophthora capsici Leonian, is an important plant disease that causes significant losses in bell pepper (Capsicum annuum L.) and other fruit and vegetable crops such as eggplant (Solanum melongena L. var. esculentum Nees), squash (Cucurbita pepo L. var. condensa Bailey), and watermelon (Citrullus lanatus (Thunb.) Matsum. \& Nakai) (19,23,25). This pathogen has been a major problem in Florida, California, Illinois, Michigan, North Carolina, New Jersey, New Mexico, and other locations throughout the world (4,14,17,26,31). P. capsici was first observed in Florida in 1931, but no major outbreaks occurred for a half century (24,33). Major outbreaks of $P$. capsici occurred in vegetable crops located in Southeast Florida in 1982, 1993, and 1998 $(24,25)$. The occurrence of Phytophthora

Corresponding author: P. D. Roberts

E-mail: pdr@ifas.ufl.edu

Accepted for publication 29 October 2005.

DOI: 10.1094/PD-90-0345

(C) 2006 The American Phytopathological Society blight has increased since 1993 throughout Florida's pepper and squash production areas $(19,24,28)$.

Phytophthora spp. require wet conditions and usually are not as good saprophytes as the eumycete Fusarium oxysporum or the oomycete Pythium spp. $(2,7,10)$. Without availability of host plants, persistence of $P$. capsici in field soil is attributed to sporangia, encysted zoospores, or as oospores if both mating types are present $(14,22,23)$. Oospore inoculum caused disease on bell pepper seedlings 12 weeks after being buried in field soil in New Jersey, and through the use of a vital stain, $9 \%$ of these oospores were deemed viable after 27 weeks (7). In Brazil, studies conducted in the greenhouse on the survival of propagules of $P$. capsici in soil indicate that sporangia and zoospores survive fewer than 75 days (2). Mycelium of $P$. capsici was shown to survive for fewer than 120 days in infected tissue (2). Recent studies in field soil indicate that oospores of $P$. capsici can survive for at least 343 days (R. D. French-Monar, J. B. Jones, and P. D. Roberts, unpublished results). Using molecular techniques, an epidemic of $P$. capsici on squash was shown to be caused by dormant oospores generated 5 years previously $(14,18)$.

Weeds have been shown to be alternative hosts for several plant pathogens, whether bacterial, fungal, or viral in origin $(1,5,6,9,15,16)$. A Phytophthora sp. that has been extensively studied due to its historical significance is $P$. infestans, the causal agent of late blight on potato. Erwin and Ribeiro (10) list 47 Solanum spp. that serve as hosts to $P$. infestans, most of which are weeds. Some other weed hosts for $P$. infestans may be found in the genera Datura, Geranium, and Ipomoea. Recent studies conducted in commercial squash fields in south Florida determined that common purslane (Portulaca oleracea L.) was an alternative host for $P$. capsici $(24,25)$. Other weeds that were not found to harbor $P$. capsici include: common beggar's tick (Bidens alba L.), black medic (Medicago lupulina L.), foxtail (Setaria verticillata (L.) P. Beauv.), jungle ricegrass (Echinochloa colonum (L.) Link), knot grass (Paspalum distichum L.) pangola grass (Digitaria decumbens Stent), spiny amaranth (Amaranthus spinosus L.), and Virginia pepperweed (Lepidium virginicum L.). In host range and characterization studies conducted by Tamietti and Valentino (31) and Tian and Babadoost (32), $P$. capsici caused disease on black nightshade (Solanum nigrum).

The objectives of this study were to determine if $P$. capsici occurs on the roots of weeds in commercial vegetable farms in Palm Beach County, characterize the isolates of $P$. capsici recovered, and assess the importance of weeds as alternative hosts for this pathogen. Portions of this research have been previously reported (11).

\section{MATERIALS AND METHODS}

Field sites. Commercial vegetable fields, where Phytophthora blight occurred sometime within 12 months before study initiation in August 2001, were sampled in Palm Beach County, located in southeastern Florida. Four field sites also had $P$. capsici on pepper during fall 2001. A total of nine locations were sampled once each during August 2001, December 2001, and March 2002. During the August sampling, fields had been tilled in preparation for the fall vegetable growing season. In the first week of December, peppers had already 
reached maturity and were harvested at least twice. In the first week of March, peppers had been mowed and farms had planted lettuce or had left the field fallow. Based on a field survey conducted prior to sampling, the following weeds were prevalent in most field sites: nightshades ( $\mathrm{So}$ lanum spp.), Carolina geranium (Geranium carolinianum L.), common purslane (Portulaca oleracea L.), common ragweed (Ambrosia artemisiifolia L.), purple nutsedge (Cyperus rotundus L.), and yellow nutsedge ( $C$. esculentus L.). Except for common purslane, other weeds previously tested by Ploetz et al. (25) were not prevalent in Palm Beach County field sites sampled, and furthermore they had been ruled out as alternative hosts of $P$. capsici.

Sampling of weeds. Whole weed plants between 15 and $40 \mathrm{~cm}$ long were carefully dug out from the soil to keep the root system intact, bagged, labeled, and taken back to the laboratory for immediate processing. Weed plant samples were nonsymptomatic and roots looked healthy, with little or no root discolorations or lesions.

Roots were thoroughly rinsed under high-pressure tap water, surface-sterilized with $70 \%$ ethanol for about $45 \mathrm{~s}$, and blotted dry. Crown and root tissue were plated on PARPH, a selective medium for isolation of Phytophthora spp. (20). Plates were incubated for 3 to 8 days in the dark at $24^{\circ} \mathrm{C}$ (16). Suspect colonies were cleaned of any possible bacterial contamination using a Van Tieghem cell (10). Identification of species was based on sporangial and oogonial morphometrics through the use of taxonomic keys for the genus Phytophthora $(3,10,29,30)$.

Polymerase chain reaction (PCR) identification of isolates. Isolates were tested using PCR to validate morphological identification as $P$. capsici. DNA was extracted from mycelium of the isolates using a modified phenol: chloroform extraction method (13). DNA was amplified using the primer PCAP in combination with the universal primer ITS 1 (27). Confirmation of $P$. capsici was obtained when amplification of an approximately 172-bp product was observed on $1 \%$ agarose gels containing a molecular size standard for size approximation. This primer combination will also amplify $P$. citricola and $P$. citrophthora. However, the amplification product for $P$. citrophthora is closer to 200-bp, and this species can be differentiated from $P$. capsici by morphological characteristics such as sporangia being noncaducous $(10,30)$. Although the amplification product of $P$. citricola is of similar size to $P$. capsici, this species can be differentiated from $P$. capsici since it is homothallic and has different morphological characteristics such as noncaducous, semipapillate sporangia.

Comparison of ITS region by sequencing. Using the DNA from one isolate of $P$. capsici obtained from each weed species, the ITS region (ITS1, 5.8S rRNA gene, ITS2) was amplified, sequenced, and compared with known sequences of $P$. capsici obtained from bell pepper from similar fields in Florida and those found by doing a BLAST search.

The complete ITS region for each isolate tested was amplified with primer ITS 4 (5'-TCCTCCGCTTATTGATATGC) paired with primer ITS 5 (5'-GGAAGTAAAAGT CGTAACAAGG). The amplification of the ITS region was conducted in a thermocycler (PTC-100; MJ Research Inc., Waltham, MA) as described by Nakasone (21) with the following cycle parameters: $94^{\circ} \mathrm{C}$ for $2 \mathrm{~min}, 30$ cycles of $93^{\circ} \mathrm{C}$ for $30 \mathrm{~s}$, $53^{\circ} \mathrm{C}$ for $2 \mathrm{~min}, 72^{\circ} \mathrm{C}$ for $2 \mathrm{~min}$, and a final extension of $10 \mathrm{~min}$ at $72^{\circ} \mathrm{C}$. Amplification of products of the correct size was verified on $1 \%$ agarose gels. The remaining product was purified with a PCR prep kit (QIAGEN Inc., Valencia, CA). Two sets of purified PCR products per isolate were submitted for sequencing to the Interdisciplinary Center for Biotechnology Research DNA Sequencing Laboratory, University of Florida, Gainesville. All ITS sequences were edited to include the complete ITS1, 5.8S ribosomal RNA gene, and ITS2 sequences.

Mating type determination. Isolates of P. capsici were grown on $20 \%$ clarified $\mathrm{V} 8$ juice (CV8) agar and crossed with known testers for A1 (isolate Cp30) and A2 (isolate $\mathrm{Cp} 32$ ) mating types (obtained from D. J. Mitchell, The Phytophthora Collection, Plant Pathology Department, University of Florida, Gainesville). A 5-mm-diameter plug of noncolonized $10 \%$ CV8 agar was sandwiched between a plug of either an A1 or A2 tester mycelium and the isolate of unknown compatibility type. After 4 days incubation at $25^{\circ} \mathrm{C}$, the middle plug was examined under the microscope for oospore formation (20).

In vitro fungicide sensitivity. Cultures of the isolates were grown on $20 \%$ CV8 agar for 4 to 6 days. Agar disks of approximately $6 \mathrm{~mm}$ diameter from actively growing edges of the colony were placed at the center of petri plates containing $20 \%$ CV8 agar media amended with 0,5 , or 100 $\mu \mathrm{g} / \mathrm{ml}$ mefenoxam (Ridomil Gold EC; $48 \%$ a.i., suspended in sterile deionized water). The fungicide was diluted in sterile water prior to adding it to the autoclaved media after it had cooled to $50^{\circ} \mathrm{C}$ (18). Four replicate plates per fungicide concentration were tested for each isolate. Plates were incubated at $24^{\circ} \mathrm{C}$ for $72 \mathrm{~h}$ and colony diameters were measured. Percent growth of each isolate on amended media was calculated by subtracting the inoculation plug diameter from the diameter of the colony, then dividing the average diameter of the colony on amended plates by the average diameter of the colony on unamended control plates (8). An isolate was characterized as sensitive if colony growth on media amended with $5 \mu \mathrm{g} / \mathrm{ml}$ me- fenoxam was less than $40 \%$ of its growth on nonamended media. Intermediate isolates grew greater than $40 \%$ of the control at $5 \mu \mathrm{g} / \mathrm{ml}$ but less than $40 \%$ of that on unamended media at $100 \mu \mathrm{g} / \mathrm{ml}$. Resistant isolates grew greater than $40 \%$ of that on unamended media at $100 \mu \mathrm{g} / \mathrm{ml}(23)$.

Pathogenicity tests on bell pepper. To further characterize isolates of $P$. capsici recovered from weeds as being plant pathogenic, pathogenicity tests were carried out in the greenhouse on bell pepper seedlings (Sakata Hybrid X pp6115). Inoculum of $P$. capsici was produced on autoclaved grains of wheat (Triticum aestivum L.) according to Mitchell and Kannwischer-Mitchell (20). Approximately $20 \mathrm{~g}$ of grains plus $25 \mathrm{ml}$ of deionized water were added to a 250-ml flask and allowed to soak overnight. Flasks were autoclaved two times on two consecutive days for 30 min. Isolates of $P$. capsici were individually grown on $20 \%$ CV8 agar for 5 days. At this point, 5-mm-diameter disk plugs were added to the water-soaked seeds and incubated for 3 weeks at $25^{\circ} \mathrm{C}$. Infested seed was finely ground in a Black \& Decker HC3000 Mincer/Chopper and mixed at $1 \mathrm{~g}$ of infested wheat seed per $\mathrm{kg}$ of soil. Soil mix was a 1:1 mixture of sterile Immokalee fine sand soil and MetroMix 500 soilless mix. One 5 -week-old bell pepper seedling was added to infested soil in each of four $10-\mathrm{cm}$-diameter pots per isolate per experiment. Experiments were conducted three times. Disease was assessed daily. Seedlings were monitored for mortality for up to 4 weeks. Samples of diseased seedlings were plated immediately after mortality onset, while any surviving plants were plated after 4 weeks.

Pathogenicity tests on weeds. A subgroup of isolates of $P$. capsici obtained from a specific weed was tested on that weed species in greenhouse experiments. Isolates or a subset of isolates obtained from a Solanum sp. were also tested on the roots of solanaceous weeds which are problematic or may pose a problem in Florida: black nightshade ( $S$. nigrum), Carolina horsenettle (S. carolinense), cockroachberry (S. capsicoides), and eastern black nightshade ( $S$. ptycanthum). Seeds of Portulaca oleracea and S. ptycanthum were obtained commercially from Valley Seed Service (Fresno, CA); seeds for $S$. americanum, $S$. capsicoides, $S$. carolinense, and $S$. nigrum were obtained from Mark Elliot (R. Charudattan laboratory, Plant Pathology Department, University of Florida), and seeds for $G$. carolinianum were obtained from Daniela Bell (L. Galloway laboratory, Biology Department, University of Virginia). Two isolates of $P$. capsici, Cp30 and Cp32, were also tested for pathogenicity on all weeds. Isolates $\mathrm{Cp} 30$ and $\mathrm{Cp} 32$ were isolated from bell pepper in Palm Beach County in 1997 and 1998, respectively. Approximately 8-weekold weed plants were inoculated using the 
same method described above (24). Eight weed plants were used per isolate in each experiment. Diseased root and crown tissue were plated on PARPH medium immediately when a plant was observed to be dead or after 7 weeks for asymptomatic plants. The experiments were conducted twice.

Statistical analysis. Pathogenicity experiments on bell pepper and weeds were arranged in a completely randomized block design with four and eight replications, respectively. Experiments were conducted three times for bell peppers and twice for weeds. Data from the weed experiments were pooled because homogeneity of variance was confirmed by Bartlett's test (12). Data from each variable was arcsine transformed before analysis of variance (ANOVA) was conducted using SAS (Release 8.02 Level 02M0 for Windows; SAS Institute Inc., Cary, NC). Mean comparisons were conducted using Fisher's protected least significant difference (FLSD, $P \leq 0.05$ ) test.

\section{RESULTS}

Isolation and identification of Phytophthora spp. from weed roots. Phytophthora spp. were obtained from 16 of 384 root systems sampled. Twelve isolates were classified as $P$. capsici (Table 1). These isolates had semi-papillate to papillate sporangia, caducous sporangia with pedicels that exceeded $35 \mu \mathrm{m}$ in length, exhibited heterothallism, and did not produce chlamydospores (Fig. 1). When paired with an opposite mating type, oospores produced were mostly aplerotic; oogonia averaged between 36 and $38 \mathrm{mi}-$ crons in diameter and were amphigynous in their antheridial attachment. $P$. capsici was isolated from the roots of two Portulaca oleracea plants, six Geranium carolinianum plants, and four $S$. americanum plants. No isolates of $P$. capsici were recovered during August 2001, one was recovered in December 2001, and the remaining 11 were recovered in March 2002. All isolates are being stored in the Phytophthora Collection, Southwest Florida Research and Education Center, Immokalee.
Mating type determination. Eleven out of 12 isolates of $P$. capsici were of mating type A1 (Table 1). One of six isolates from Carolina geranium, CWG1-4, was of the A2 mating type.

Fungicide sensitivity. All isolates of $P$. capsici obtained from weeds were resistant to mefenoxam. At 100 ppm of mefenoxam, growth of isolates CWG1-1, CW1-2, CWG1-3, CWG1-4, CWG1-5a, CWG15b, CoPur3-1, CoPur3-2, NSh7-1, NSh7-2, NSh7-3, and NSh7-4, were 78, 83, 85, 91, 68, 86, 74, 94, 57, 100, 107, and 76\%, respectively, compared with that of the unamended control.

PCR identification of Phytophthora isolates. The two isolates from Portulaca oleracea, six from $G$. carolinianum, four from $S$. americanum, and one from $A$. artemisiifolia produced a PCR product with primers PCAP and ITS 1. All amplification products were of the expected 172 bp for $P$. capsici except for the isolate from A. artemisiifolia, which amplified a slightly larger region of about $200 \mathrm{bp}$ (Fig. 2) (27). Based on taxonomic keys, fragment size (27), and morphological characteristics such as noncaducous sporangia (10), this isolate was identified as $P$. citrophthora.

Comparison of ITS region. The ITS region of one isolate per weed host was amplified, sequenced, and used for comparison with other sequences reported for $P$. capsici. One isolate of $P$. capsici from G. carolinianum (CWG1-3), Portulaca oleracea (CoPur3-1), and S. americanum (NSh7-2 ) were randomly tested. These three isolates contained identical 752-bp sequences for the ITS region:

5'CCACACCTAAAAAACTTTCCACGT GAACCGTATCAACCCTTTTAGTTGGG GGTCTTGTACCCTATCATGGCGAATG TTTGGACTTCGGTCCGGGCGAGTAG CTTTTTGTTTTAAACCCATTTCACAAT TCTGATTATACTGTGGGGACGAAAGT CTCTGCTTTTAACTAGATAGCAACTT TCAGCAGTGGATGTCTAGGCTCGCA CATCGATGAAGAACGCTGCGAACTG CGATACGTAATGCGAATTGCAGGATT CAGTGAGTCATCGAAATTTTGAACG CATATTGCACTTCCGGGTTAGTCCTG GGAGTATGCCTGTATCAGTGTCCGTA

Table 1. Isolates of Phytophthora capsici recovered from weeds, host of origin, mating type, and pathogenicity on bell pepper seedlings

\begin{tabular}{lllcc}
\hline Isolate & \multicolumn{1}{c}{$\begin{array}{c}\text { Host } \\
\text { (common name) }\end{array}$} & $\begin{array}{c}\text { Host } \\
\text { (binomial) }\end{array}$ & $\begin{array}{c}\text { Mating } \\
\text { type }\end{array}$ & $\begin{array}{c}\text { \% Pepper } \\
\text { mortality }\end{array}$ \\
\hline CoPur3-1 & Common purslane & Portulaca oleracea & A1 & 100.0 \\
CoPur3-3 & Common purslane & P. oleracea & A1 & 100.0 \\
CWG1-1 & Carolina geranium & Geranium carolinianum & A1 & 37.5 \\
CWG1-2 & Carolina geranium & G. carolinianum & A1 & 100.0 \\
CWG1-3 & Carolina geranium & G. carolinianum & A1 & 100.0 \\
CWG1-4 & Carolina geranium & G. carolinianum & A2 & 100.0 \\
CWG1-5a & Carolina geranium & G. carolinianum & A1 & 100.0 \\
CWG1-5b & Carolina geranium & G. carolinianum & A1 & 100.0 \\
NSh7-1 & American black nightshade & Solanum americanum & A1 & 100.0 \\
NSh7-2 & American black nightshade & S. americanum & A1 & 100.0 \\
NSh7-3 & American black nightshade & S. americanum & A1 & 100.0 \\
NSh7-4 & American black nightshade & S. americanum & A1 & 100.0 \\
\hline
\end{tabular}

CATCAAACTTGGCTTTCTTCCTTCCG TGTAGTCGGTGGAGGATGTGCCAGA TGTGAAGTGTCTTGCGTGTTGTCCTT CGGGTCGACTGCGAGTCCTTTTAAAT GTACTGAACTGTACTTCTCTTTGCTC GAAAAGCGTGGTGTTGCTGGTTGTG GAGGCTGCCTGCGTGGCCAGTCGGC GACCGGTTTGTCTGCTGCGGCGTTTT AAGGAGGAGTGTTCGATTCGCGGTA TGGTTGGCTTCGGCTGAACAGGCGC TTATTGAATGCTTTTCCTGCTGTGGC GTGATGGGCTGGTGAACCGTAGCTG TGTTTGGCTTGGCTTTTGAATCGGTT TTGCTGTTGCGAAGTAGAGTGGCGG CTTCGGCTGTCGAGGGTCGATCATTT TGGGAATTTTGTGTGCACTTCGGTGC GCATCTCAA.

Pathogenicity tests on bell pepper. All isolates from Portulaca oleracea and $S$. americanum, and 5 of 6 isolates from $G$. carolinianum, caused $100 \%$ mortality of bell pepper (Table 1). One isolate, CWG11 from G. carolinianum, only caused $38 \%$ mortality of bell pepper seedlings after 4 weeks. However, P. capsici was isolated from the root system of all the surviving bell pepper plants tested with this weak isolate (data not shown).

Pathogenicity tests on weeds. $S$. nigrum was the only weed species where plant mortality occurred when soil was infested with $P$. capsici. Mortality and percent recovery of $P$. capsici from the roots of $S$. nigrum inoculated with NSh7-2 and Cp32 was $100 \%$ (Table 2). Symptoms on $S$. nigrum were dark lesions around the crown, wilting, leaf drop, and the spread of crown lesions upward along the main stem (Fig. 3). The moribund or dead S. nigrum plants had a stunted root system missing most of the secondary roots. The roots were soft, brown, and rotted throughout.

None of the $P$. capsici isolates tested on Portulaca oleracea caused plant mortality (Table 2). Incidence of $P$. capsici in roots grown in soil infested with the four isolates of $P$. capsici tested was not significantly different from the noninfested control. Isolate $\mathrm{Cp} 30$ was not detected from the roots of this weed.

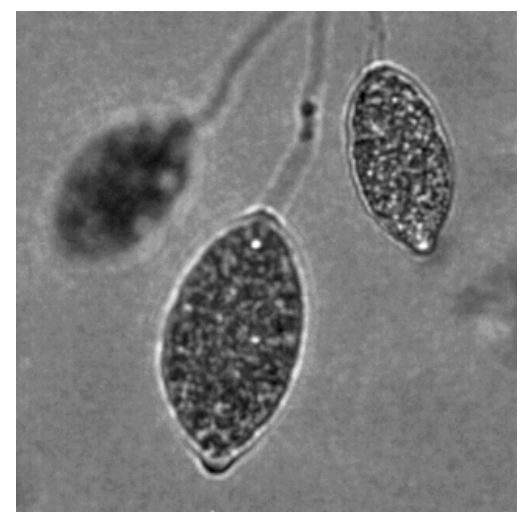

Fig. 1. Papillate sporangia of Phytophthora capsici isolate CWG1-3 obtained from the roots of Carolina geranium (Geranium carolinianum) in Palm Beach County, FL. 
No mortality occurred among plants of $G$. carolinianum tested with six different isolates of $P$. capsici (Table 2). Incidence of plants with root colonization varied among isolates. Statistically, isolates grouped into three different categories of root colonization, ranging from 31 to $81 \%$. The two highest colonization rates occurred with isolates CWG1-2 and CWG14 , both originally isolated from G. carolinianum.

None of the six isolates of $P$. capsici tested on $S$. ptycanthum were capable of causing plant mortality or disease symptoms (Table 2). Incidence of plants with root colonization varied among isolates. Except for isolate $\mathrm{Cp} 30$, which was only recovered from $38 \%$ of root samples, all other isolates tested were detected in at least $75 \%$ of the root samples plated on the selective medium for $P$. capsici. Isolate NSh7-2 was recovered from all root samples.

S. capsicoides had no plant mortality from the three isolates of $P$. capsici used in pathogenicity studies. $P$. capsici was not

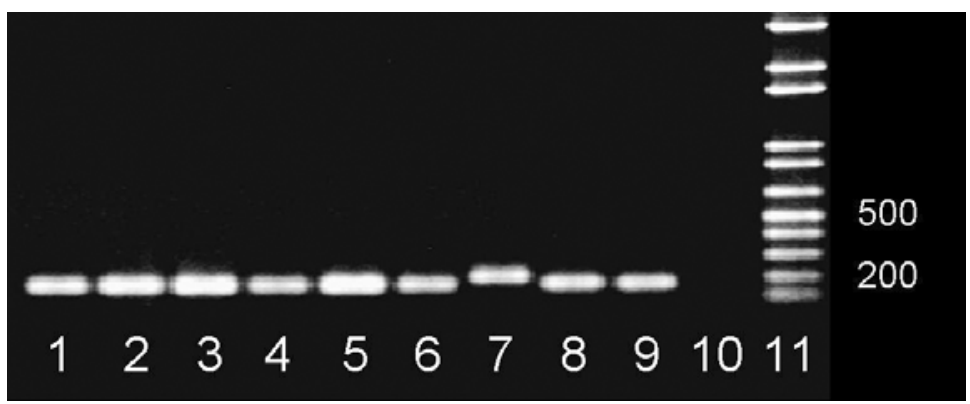

Fig. 2. DNA amplified using primers PCAP and ITS 1 of isolates of Phytophthora spp. recovered from weeds. Isolates were recovered from Solanum americanum (lanes 1 to 4), Portulaca oleracea (lanes 5 and 6), and Ambrosia artemisiifolia (lane 7). Isolates Cp10 (lane 8) and Cp32 (lane 9) were used as positive controls. Lane 10 contains a no-template control. Lane 11 contains a 100-bp ladder.

Table 2. Pathogenicity of isolates of Phytophthora capsici on six weeds expressed as plant mortality and incidence of plants with roots colonized by $P$. capsici $^{\mathrm{Z}} 49$ days postinoculation

\begin{tabular}{|c|c|c|c|c|}
\hline Weed & Isolate & Isolate origin & $\begin{array}{c}\text { Mortality } \\
(\%)\end{array}$ & $\begin{array}{c}\text { Incidence } \\
(\%)\end{array}$ \\
\hline Geranium carolinianum & Control & $\ldots$ & 0.0 & $0.0 \mathrm{a}$ \\
\hline G. carolinianum & CWG1-3 & G. carolinianum & 0.0 & $31.3 \mathrm{~b}$ \\
\hline G. carolinianum & Cp30 & Capsicum аппиит & 0.0 & $31.3 \mathrm{~b}$ \\
\hline G. carolinianum & Cp32 & C. апnиит & 0.0 & $56.3 \mathrm{c}$ \\
\hline G. carolinianum & CWG1-2 & G. carolinianum & 0.0 & $81.3 \mathrm{~d}$ \\
\hline G. carolinianum & CWG1-4 & G. carolinianum & 0.0 & $81.3 \mathrm{~d}$ \\
\hline Portulaca oleracea & Control & $\ldots$ & 0.0 & $0.0 \mathrm{a}$ \\
\hline P. oleracea & Cp30 & C. anпuит & 0.0 & $0.0 \mathrm{a}$ \\
\hline P. oleracea & CoPur3-1 & P. oleracea & 0.0 & $12.5 \mathrm{ab}$ \\
\hline P. oleracea & CoPur3-3 & P. oleracea & 0.0 & $12.5 \mathrm{ab}$ \\
\hline P. oleracea & Cp32 & C. аппиит & 0.0 & $25.0 \mathrm{ab}$ \\
\hline Solanum americanum & Control & $\ldots$ & 0.0 & $0.0 \mathrm{a}$ \\
\hline S. americanum & $\mathrm{Cp} 30$ & C. аппиит & 0.0 & $0.0 \mathrm{a}$ \\
\hline S. americanum & NSh7-2 & S. americanum & 0.0 & $12.5 \mathrm{a}$ \\
\hline S. americanum & NSh7-2 & S. americanum & 0.0 & $12.5 \mathrm{a}$ \\
\hline S. americanum & Cp32 & C. annuиm & 0.0 & $62.5 \mathrm{~b}$ \\
\hline Solanum carolinense & Control & $\ldots$ & 0.0 & $0.0 \mathrm{a}$ \\
\hline S. carolinense & Cp30 & C. аппиит & 0.0 & $0.0 \mathrm{a}$ \\
\hline S. carolinense & NSh7-1 & S. americanum & 0.0 & $0.0 \mathrm{a}$ \\
\hline S. carolinense & NSh7-2 & S. americanum & 0.0 & $12.5 \mathrm{a}$ \\
\hline S. carolinense & Cp32 & C. annuum & 0.0 & $25.0 \mathrm{a}$ \\
\hline Solanum nigrum & Control & $\ldots$ & $0.0 \mathrm{a}$ & $0.0 \mathrm{a}$ \\
\hline S. nigrum & Cp30 & C. annuиm & $62.5 \mathrm{~b}$ & $75.0 \mathrm{~b}$ \\
\hline S. nigrum & Cp32 & C. аппиит & $100.0 \mathrm{~b}$ & $100.0 \mathrm{c}$ \\
\hline S. nigrum & NSh7-1 & S. americanum & $100.0 \mathrm{~b}$ & $100.0 \mathrm{c}$ \\
\hline S. nigrum & NSh7-2 & S. americanum & $100.0 \mathrm{~b}$ & $100.0 \mathrm{c}$ \\
\hline Solanum ptycanthum & Control & $\ldots$ & 0.0 & $0.0 \mathrm{a}$ \\
\hline S. ptycanthum & Cp30 & C. anпиum & 0.0 & $37.5 \mathrm{~b}$ \\
\hline S. ptycanthum & NSh7-1 & S. americanum & 0.0 & $75.0 \mathrm{c}$ \\
\hline S. ptycanthum & NSh7-3 & S. americanum & 0.0 & $75.0 \mathrm{c}$ \\
\hline S. ptycanthum & Cp32 & C. аппиит & 0.0 & $87.5 \mathrm{c}$ \\
\hline S. ptycanthum & NSh7-2 & S. americanum & 0.0 & $100.0 \mathrm{c}$ \\
\hline
\end{tabular}

$\mathrm{z}$ Values for each variable were arcsine transformed before analysis. Data for each variable within each weed were pooled for statistical analysis because homogeneity of variance was confirmed by Bartlett's test. Values within columns for each weed followed by the same letter are not significantly different $(P>0.05)$ according to Fisher's protected least significant difference. Values in a column not followed by letters are not significantly different. isolated from the roots. S. carolinense exhibited no plant mortality from $P$. capsici, but the pathogen did colonize some of the root samples inoculated with isolates Cp32 and NSh7-2 (Table 2). However, incidence of plants with root colonization did not exceed $25 \%$.

Plants of S. americanum also had $0 \%$ mortality rate among the plants tested with four isolates of $P$. capsici (Table 2). However, there was a significant difference in root colonization levels by $P$. capsici depending on the isolate used. Incidence of plants with root colonization ranged from $0 \%$ for isolate $\mathrm{Cp} 30$ to $63 \%$ for isolate Cp32.

\section{DISCUSSION}

Weeds as alternative hosts for $P$. capsici in Florida were first examined by Ploetz and Haynes (24) in Miami-Dade County. They identified Portulaca oleracea as an alternative host for this pathogen with low levels of root colonization. These low levels of root colonization by $P$. capsici on Portulaca oleracea were confirmed for Palm Beach County in our study. When Portulaca oleracea is well managed, as was the case in several Palm Beach County farms surveyed, this weed may not be an important source for initial inoculum of $P$. capsici during the growing season. During the off-season, when land is fallow, weeds are not managed and populations increase. Portulaca oleracea may serve as an alternative host for the overseasoning of $P$. capsici. For the many diseases caused by various Phytophthora spp., including $P$. capsici, low levels of initial inoculum can lead to significant disease outbreaks and initiate a future disease outbreak (10).

$G$. carolinianum and $S$. americanum were also found to be alternative hosts for $P$. capsici under natural field conditions. These two weeds have not been previously reported as alternative hosts for $P$. capsici. In the greenhouse trials, $P$. capsici was more successful in colonizing G. carolinianum (31 to $81 \%$ recovery from root samples) and S. americanum (0 to 63\% recovery from root samples) compared with Portulaca oleracea (0 to $25 \%$ recovery from root samples). Although P. capsici was recovered at high percentages from G. carolinianum, the five isolates did not cause root lesions, mortality, or other visible symptoms of disease on this plant This data could indicate that $P$. capsici may be surviving in this weed as a weak pathogen or a root colonizer $(24,25)$. In greenhouse studies, in addition to $S$. americanum, other Solanum spp. were found to be alternative hosts of $P$. capsici. $S$. nigrum was the only weed species in which $P$. capsici colonized the roots and caused plant mortality. S. nigrum may represent a significant source for survival of $P$. capsici if it ever gets established in Florida. S. carolinense was also colonized by $P$. capsici, although at very low levels. 
Roots of $S$. capsicoides were not colonized by the isolates of $P$. capsici tested in these experiments. This study recovered $P$. capsici from two weed species not previously reported as alternative hosts for this pathogen. Sampling of other weeds prevalent in other agricultural regions might reveal a larger host range for $P$. capsici.

One field site had both the A1 and A2 mating types isolated from G. carolinianum, although on separate plants. The fact that both mating types of $P$. capsici were found surviving on weeds would indicate that genetic recombination could take place in the absence of susceptible crop hosts. In Florida, Ploetz et al. (25) isolated both mating types from the same squash plants. A similar occurrence could be happening on weeds.

All isolates of $P$. capsici obtained from weeds were resistant to mefenoxam. Although higher and lower levels of resistance have been found in isolates of $P$. capsici from vegetable fields throughout South Florida, the trend in the population of $P$. capsici is toward resistance $(24,25 ; \mathrm{R}$. D. French-Monar, unpublished). Two isolates sensitive to mefenoxam, Cp30 and $\mathrm{Cp} 32$, colonized the weeds during the greenhouse pathogenicity trials. The recovery of only resistant isolates in the field may be due to the use of mefenoxam during the growing season, which selects for resistant isolates which then are available to colonize weeds.

The isolates of $P$. capsici recovered from weeds were identical, based upon the sequence of the ITS region, to other isolates of $P$. capsici from bell pepper in Palm Beach County in previous years (R. D. French-Monar, unpublished). A nucleotidenucleotide BLAST search from the National Center for Biotechnology Informa-

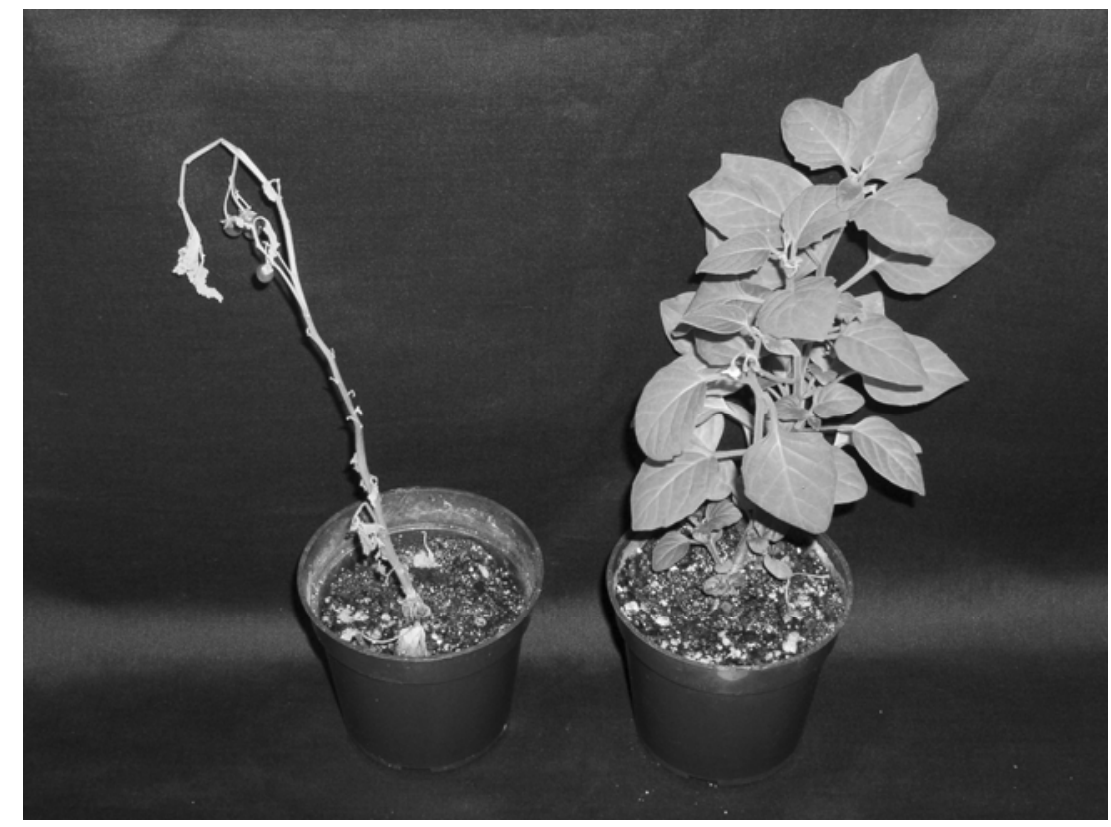

Fig. 3. Extensive leaf drop and stem rot on Solanum nigrum plant inoculated with Phytophthora capsici isolate NSh7-2 (left) and noninoculated (right).

tion revealed one identical sequence (GenBank accession no. AY208129) and eight almost identical sequences that were different in one nucleotide (AJ854286, AJ854287, AY208130, AY742735, AY742736) or two (AJ854284, AJ854285, AY7266623). All these reported sequences belong to $P$. capsici. Based on the sequence of the ITS region, the isolates from weeds showed no variation from those that infect vegetable crops. $P$. capsici from vegetable crops may have adapted to weeds in this area, which could now serve as potential sources of initial inoculum.

In many field sites sampled in this study, it was difficult to find weeds close to bell pepper beds at the beginning of the growing season due to intensive weed management practices carried out by many growers, who apply herbicides to row centers while bell pepper plants are small. Weeds could still be found in proximity to the fields, especially along roadways or irrigation canals. Other farms, where weeds are less successfully managed, could potentially harbor a greater number and diversity in weeds that could serve as alternative hosts to $P$. capsici.

During March 2002, P. capsici was detected in all three weed species that were determined to be alternative hosts of $P$. capsici. Therefore, weed management should begin as soon as the growing season is over, since any inoculum found in weed plants at this time can potentially survive until August or September, when the next growing season begins. Even if soil is tilled and weeds incorporated into the soil, undecomposed plant material may contain inoculum that will persist in soil $(2,7,10)$. Additional methods to reduce weed populations during the summer may 
Phytophthora capsici on vegetable crops: Research progress and management challenges. Plant Dis. 88:1292-1303.

15. Hepperly, P. R., Kirkpatrick, B. L., and Sinclair, J. B. 1980. Abutilon theophrasti: Host for three fungal parasites of soybean. Phytopathology 70:307-310.

16. Hollowell, J. E., Shew, B. B., Cubeta, M. A., and Wilcut, J. W. 2003. Weed species as hosts of Sclerotinia minor in peanut fields. Plant Dis. 87:197-199.

17. Hwang, B. K., and Kim, C. H. 1995. Phytophthora blight of pepper and its control in Korea. Plant Dis. 79:221-227.

18. Lamour, K. H., and Hausbeck, M. K. 2000. Mefenoxam insensitivity and the sexual stage of Phytophthora capsici in Michigan cucurbit fields. Phytopathology 90:396-400.

19. McGovern, R. J., Roberts, P. D., Kucharek, T. A., and Gilreath, P. R. 1998. Phytopthora capsici: New problems from an old enemy. Pages 9-16 in: 1998 Florida Tomato Institute Proc., University of Florida, Gainesville

20. Mitchell, D. J., and Kannwischer-Mitchell, M. E. 1992. Phytophthora. Pages 31-38 in: Methods for Research on Soilborne Phytopathogenic Fungi. L. L. Singleton, J. D. Mihail, and C. M. Ruch, eds. American Phytopathological Society, St. Paul, MN.

21. Nakasone, K. K. 1996. Morphological and molecular studies on Auriculariopisis albomellea and Phlebia albida and a reassessment of A. ampla. Mycologia 88:762-775.

22. Papavizas, G. S., Bowers, J. H., and Johnston, S. A. 1981. Selective isolation of Phytophthora capsici from soils. Phytopathology 71:129133.

23. Parra, G., and Ristaino, J. B. 2001. Resistance to mefenoxam and metalaxyl among field isolates of Phytophthora capsici causing Phytophthora blight of bell pepper. Plant Dis. 85:1069-1075.

24. Ploetz, R. C., and Haynes, J. L. 2000. How does Phytophthora capsici survive in squash fields in southeastern Florida during the offseason? Proc. Fla. State Hortic. Soc. 113:211215.

25. Ploetz, R. C., Heine, G., Haynes, J., and Watson, M. 2002. An investigation of biological attributes that may contribute to the importance of Phytophthora capsici as a vegetable pathogen in Florida. Ann. Appl. Biol. 140:6167.

26. Ristaino, J. B., and Johnston, S. A. 1999. Ecologically based approaches to management of Phytophthora blight on bell pepper. Plant Dis. 83:1080-1089.

27. Ristaino, J. B., Madritch, M., Trout, C. L., and Parra, G. 1998. PCR amplification of ribosomal DNA for species identification in the plant pathogen genus Phytophthora. Appl. Environ. Microbiol. 64:948-954.

28. Roberts, P. D., McGovern, R. J., Hert, A. Vavrina, C. S., and Urs, R. R. 1999. Phy tophthora capsici on tomato: Survival, severity, age, variety, and insensitivity to mefenoxam. Pages 41-43 in: Florida Tomato Institute Proc. C. S. Vavrina, ed. University of Florida and Citrus \& Vegetable Magazine PRO 516.

29. Stamps, D. J. 1985. Phytophthora capsici. Commonw. Mycol. Inst. Descriptions of Pathogenic Fungi and Bacteria. No. 835.

30. Stamps, D. J., Waterhouse, G. M., Newhook, F. J., and Hall, G. S. 1990. Revised tabular key to the species of Phytophthora. Mycological Papers, no. 162. Commonwealth Agricultural Bureau, International Mycological Institute, Kew, England.

31. Tamietti, G., and Valentino, D. 2001. Physiological characterisation of a population of $P h y-$ tophthora capsici Leon. from northern Italy. J. Plant Pathol. 83:199-205.

32. Tian, D., and Babadoost, M. 2004. Host range of Phytophthora capsici from pumpkin and pathogenicity of isolates. Plant Dis. 88:485489.

33. Weber, G. F. 1932. Blight of peppers in Florida caused by Phytophthora capsici. Phytopathology 22:775-780. 